\title{
PHYSMOD 2011 参加報告 \\ International Workshop on Physical Modelling of Flow and Dispersion Phenomena
}

\author{
樋山恭助*1 加藤信介 ${ }^{* 2}$ 中尾圭佑 ${ }^{* 3}$
}

Kyosuke HIYAMA, Shinsuke KATO, Keisuke NAKAO

国際会議 Physical Modelling of Flow and Dispersion Phenomena (PHYSMOD 2011) が 8 月 22 日-24 日に, ドイツ・ハンブルグで行われた。Scientific Committee のメンバーとして参加した著者の立場から, 本会議の様 子を報告する。

\section{1. 参加会議の概要}

本会議は Hamburg 大学主催の下, Hamburg 大学 B. Leitl 教授が事務局となり開催された。開催場所は, 前 回の同会議の際に, 次回開催地の公募と投票が行われ, 多数得票により決定されることが慣例となっている。 なお，「 EMPA/ETH (Switzerland)」， $\lceil$ EnFlo/University of Surrey (UK) 」, 「Ecole Centrale de Nantes (France)」, 「Institute of Thermomechanics AS CZ (Czech Republic)」が次回 開催地として立候補している（2011 年 11 月 11 日時 点)。

Conference Proceedingsによれば，論文数は 47 編 であった。内訳は, Session 1 Basic Studies : 17 編, Session 2 Validation : 13 編, Session 3 Applied Physical Modelling：17編となる。拡散現象の風洞実
験フフィールド実験，これらの結果をバリデーション データとして用いた CFD 解析に関する発表が多かっ た。特に, 風洞実験に関しては, 研究内容のみでなく, その方法論に関して積極的な議論が行われており，実 験技術の継承・錬磨の場として，貴重な位置づけをも つ国際会議であるとの印象を受けた。

事務局からのレポートでは, 参加者は 65 名, 参加 国は 12 力国となる。アジアからの参加は日本 (10名) のみであり, 欧州からの参加者が大多数を占めていた。 会議は開会から閉会まで, Hamburg 大学 Institute of Meteorology の研究棟の一講堂で行われた。単一会場で 行われたこともあり, 各セッションとも聴講者数が多く, 発表毎に積極的な意見交換が行われていた。

\section{2. 会議日程 \\ 2. 1 日目}

会議の議長は, Hamburg 大学の B. Leitl 教授が務め た。B. Leitl 教授の開会挨拶で始まり，Hamburg 大学 の M. Schatzmann 教授の基調講演が行われた。

その後, Basic Studies Part1 Part3 の 3 セッションが 行われ，それぞれ $4-5$ 件の発表があった。著者の加藤,

* 1 東京大学 生産技術研究所 助教

Research Associate, Institute of Industrial Science, The University of Tokyo

* 2 東京大学 生産技術研究所 教授

Professor, Institute of Industrial Science, The University of Tokyo

*3 東京大学大学院 工学系研究科 建築学専攻 大学院生

Graduate Student, School of Engineering, The University of Tokyo 
中尾は Basic Study Part3 において都市の換気性状の風 洞実験結果及びその評価方法に関する発表を行い，実験 データの取扱やその評価方法に関して，有意義な意見交 換を行った。

セッション終了後, Hamburug 大学 Environmental Wind Tunnel Laboratory (EWTL)の研究施設見学と, そ の場で歓迎レセプションが行われた。長さ : $18 \mathrm{~m}$, 幅 : $4 \mathrm{~m}$, 高さ : $2.5 \mathrm{~m}$ の測定胴を持つ大型風洞「WOTAN」 (写真 1) による可視化実験のデモ等が行われ, 研究成 果等の詳しい説明が行われた。

\section{2 2日目}

BASIC STUDIES Part 4, VALIDATION Part 1 Part 3 の 4 セッションが行われ，それぞれ 4-5 件の発 表があった。セッション終了後, 港の辺に位置するドイ ツ料理レストランで WorkShop Dinner が行われた。

\section{33 日目}

APPLIED STUDY Part 1 Part 4の 4セッションが行 われ，それぞれ 4-5 件の発表があった。著者の樋山は, APPLIED STUDY Part 3 で, タイ・バンコクをケース スタディ対象とした都市の風通しの評価法に関寸る発表 を行い，その評価対象のモデリングに関して意見交換を 行った。

参加者の投票により, 若手優秀研究発表の選考が行わ れ，閉会式においてその表彰が行われた。

\section{3. 日独交流 150 周年 日独合同シンポジウム}

本国際会議の翌日，8月 25 日に，ドイツと日本の外交 関係樹立 150 周年を記念寸る政府間のイベントの一環と して, 会議と同会場において, 日独合同シンポジウム 「URBAN AREAS INA CHANGING CLIMATE 」が行 われた（写真 2)。ドイッからは，F. Feser 氏 (Helmholtz-Zentrum Geesthacht) と H. Schluenzen 教授 (Hamburug University) が，日本からは西島准 教授（Technical University of Denmark）と著者の加 藤が講演を行った。H. Schluenzen 教授及び西島准教 授は地球規模のマクロな視点から，F. Feser 氏及び加 藤は都市規模のミクロな視点から，地球環境問題に関 する議論を展開した。
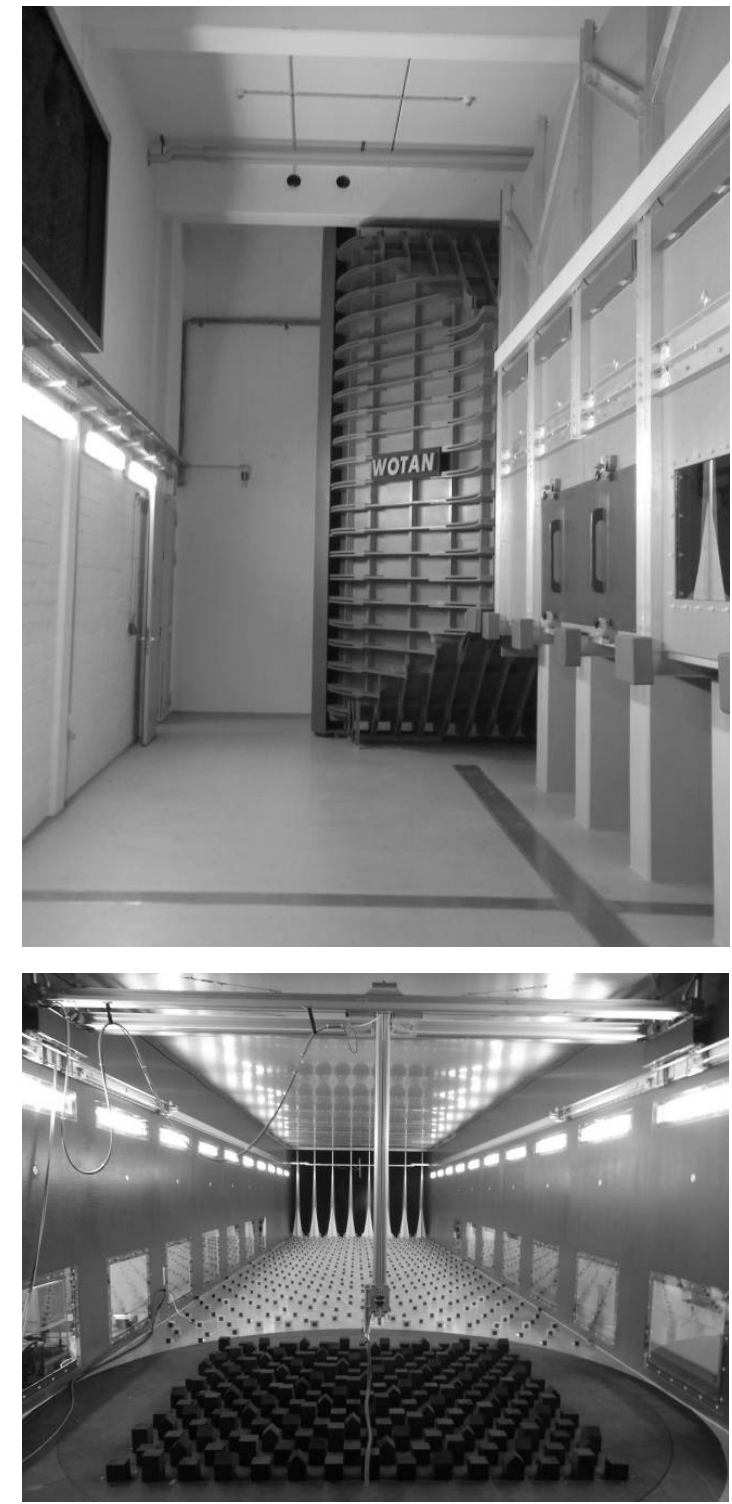

写真 1 Hamburg 大学風洞実験施設 WOTAN

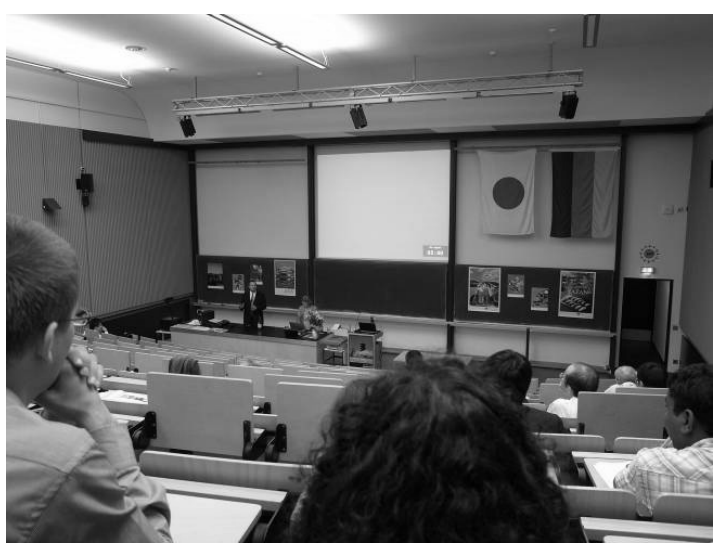

写真 2 日独合同シンポジウムの様子 